Role of agricultural engineering in environmental and sustainable development for the valley and delta areas: 1609 - 1629

\title{
MANUFACTURE OF CONCAVE SIEVES GROUP FOR SMALL THRESHER TO SUIT THRESHING LENTIL CROP
}

\author{
Wagdy Z. El-Haddad*
}

\author{
Hamada A. El-Khateeb*
}

\section{Ismail F. Sayed-Ahmed*}

\begin{abstract}
The performance of threshing machine with different concave sieves were tested and evaluated according to the following parameters: cylinder speeds $(15.14,18.18,20.21$ and $22.25 \mathrm{~m} / \mathrm{s})$, feeding rates $(8,10$, 12 and $15 \mathrm{~kg} / \mathrm{min}$ ) and holes diameter of concave sieves (11, 9 and $7 \mathrm{~mm}$ ). The experimental results revealed that both seed output, cleaning efficiency, seed damage, threshing efficiency and consumed power were maximum with cylinder speed of $22.25 \mathrm{~m} / \mathrm{s}$ and feeding rate of $15 \mathrm{~kg} / \mathrm{min}$ $(8.7 \mathrm{~kg} / \mathrm{min}, 98.99 \%, 23 \%, 97.75 \%$ and $3.23 \mathrm{~kW}$, respectively). Unthreshed seed losses and length of cut straw were minimum $(0.34 \%$ and $9.5 \mathrm{~mm}$ ) under the feed rate $8 \mathrm{~kg} / \mathrm{min}$, cylinder speed of $22.25 \mathrm{~m} / \mathrm{s}$ and hole diameter for concave sieve of $7 \mathrm{~mm}$. The criterion function cost for modification thresher machine was $66.978 \mathrm{LE} / \mathrm{Mg}$ at the same operation condition.
\end{abstract}

\section{INTRODUCTION}

$\mathrm{L}$ entil is considered one of the main leguminous crop in Egypt, as its highly nutrition value seeds, provide the human body with its needs from vegetable proteins which is relatively lower in price comparative than animal protein. Each $100 \mathrm{gm}$ of lentil seed contain 0.25 $\mathrm{gm}$ of vegetable protein, $1.3 \mathrm{gm}$ of fat, $0.07 \mathrm{gm}$ of calcium, $0.35 \mathrm{gm}$ of phosphorous, $0.01 \mathrm{gm}$ of iron as well as a number of other elements. Lentil is public foods consumed by the great majority of population (ElTatawy, 1999).

In Egypt is cultivated in total area about 8000 fed, producing about 6880 tons, where the major planting area is in Upper Egypt. Lentil plants provide high-quality straw for animals feeding and increase soil fertility. Up till now, the manual threshing of lentil crop is still the common practice followed by the majority of the farmers in Egypt. The ultimate

\footnotetext{
Agric. Eng. Res. Inst. (AEnRI) - Dokki - Giza - Egypt.
} 
purpose of threshing operation is to recover the seeds free from residues with minimum losses and maximum efficiency.

Kadry (1987) designed a prototype of lentil walker puller to pull the lentil plants under manual and mechanical planting. Three types of puller fingers of cylindrical and conical shape with clearance of $6 \mathrm{~mm}, 22-8$ $\mathrm{mm}$, and 20-6 mm were tested. The efficiency of pulling plants increased with the increasing of forward speed and rotational speed, especially under mechanically planted treatments comparing to manual method, and the highest efficiency was obtained under conical shape finger of clearance of 20-6 mm. The prototype saving is about $31 \mathrm{~L} . \mathrm{E} / \mathrm{feddan}$ (262\%) comparing with manual pulling method of lentil plants.

El-Haddad (2000) designed a simplified threshing and winnowing machine suitable for small holdings. Indicated that the rice grain output increased as the cylinder speed increased, the maximum amount of rice grain output was $9.891 \mathrm{~kg} / \mathrm{min}$ at cylinder speed $21.25 \mathrm{~m} / \mathrm{s}$ (1400 rpm), feed rate of $30 \mathrm{~kg} / \mathrm{min}$ and moisture content of $14.8 \%(\mathrm{db})$ in grain and $12 \%(\mathrm{db})$ in straw.

Morad et al. (2000) developed the reciprocating mower to be suitable for harvesting lentil crop. They found that harvesting of lentil by using the developed mower maximized both field capacity and efficiency comparing with the same mower before development and manual method. Harvesting of lentil crop by using the developed mower at a kinematic parameter of 1.33 and horizontal distance between the reel axis and the cutter bar of $10 \mathrm{~cm}$ minimized losses.

Abo El-Naga, et al. (2005) studied feasibility of cereal threshing machine for dry lentil seed threshing and select the optimum conditions for operating it. The obtained results show that the local threshing machine cane be successfully used for threshing lentil crop under the following conditions: feeding rate of $11.67 \mathrm{~kg} / \mathrm{min}$ and drum speed of $11.78 \mathrm{~m} / \mathrm{sec}$ at seed moisture content of $10.31 \%$, resulting in seed damage of $0.62 \%$, unthreshed seed of $0.15 \%$, total seed losses of $0.77 \%$, seed output of $302.1 \mathrm{~kg} / \mathrm{h}$, threshing efficiency of $99.79 \%$ consumed energy of $0.116 \mathrm{~kW} . \mathrm{h} / \mathrm{kg}$ and criterion cost of $85.83 \mathrm{~L} . \mathrm{E} / \mathrm{ton}$.

Emara (2006) modified local stationary threshed for threshing the flax crop has been evaluated and tested under different operating conditions. 
He reported that the maximum values of seed output and threshing efficiency in addition to the minimum values of total seed losses, stalks damage and energy requirements for all drum speeds and feed rates, compared with the machine before development.

Moussa (2006) investigate of the performance threshing machine for different legume crops (Soybean, lentil and chickpea). He illustrated that the highest values of threshing efficiency were $98.74,97.68$ and $97.46 \%$ with feed rates of 600,800 and $900 \mathrm{~kg} / \mathrm{h}$, respectively, at drum speed 14 $\mathrm{m} / \mathrm{s}$ and grain moisture content $10.12 \%$ for lentil crop. Meanwhile, the lowest threshing efficiency were $97.78,96.25$ and $95.33 \%$ at feed rates of 600,800 and $900 \mathrm{~kg} / \mathrm{h}$, respectively, at drum speed $10 \mathrm{~m} / \mathrm{s}$ and grain moisture content $13.78 \%$ for lentil crop.

Afify et al. (2007) developed a small thresher to suit threshing of Black seed. The thresher results showed that the minimum total seed losses of $2.63 \%$, stripping efficiency of $99.31 \%$, threshing efficiency of $98.74 \%$, cleaning efficiency of $95.88 \%$, required energy of $2.85 \mathrm{~kW} . \mathrm{h} / \mathrm{ton}$ and criterion cost of $199.18 \mathrm{~L}$.E/ton were recorded under drum speed of 6.28 $\mathrm{m} / \mathrm{s}$, feed rate of $600 \mathrm{~kg} / \mathrm{h}$ and capsules moisture content of $13.63 \%$.

Mahmoud et al. (2007) developed feeding device of a Turkish threshing machine to increase machine efficiency and avoid many traumatic injuries during threshing process. They found that using threshing machine with the constructed feeding device decreased unthreshed grain losses by $26.99 \%$, mechanical grain damage by $40.37 \%$ and total grain losses by $34.85 \%$. In addition, threshing efficiency increased by $0.62 \%$ cleaning efficiency increased by $3.0 \%$, energy requirement increased by $3.49 \%$ and finally threshing cost decreased by $14.27 \%$ at material feed rate of $1100 \mathrm{~kg} / \mathrm{h}$, drum speed of $27 \mathrm{~m} / \mathrm{s}$ and grain moisture content of $19 \%$.

\section{The objectives of the present study are:}

1. To manufacture of concave sieves group for small thresher and chose the best for threshing lentil crop.

2. To evaluate the performance of machine with different concave sieves for threshing lentil crop.

3. To investigate and test the influence of cylinder peripheral speed, feed rates and holes diameter for concave sieves on all studied variables. 


\section{MATERIAL AND METHODS}

\subsection{The small thresher:}

This machine was built to satisfy the Egyptian farmers requirements. It was designed and constructed by (El-Haddad, 2000) for threshing and winnowing rice crop for small holdings. The present machine specifications: as shown in Table 1 and Figs. 1.

A study was conducted to manufacture of concave sieves group for small thresher and chose very best types for threshing lentil crop.

\subsubsection{Concave sieves specifications:}

Type: perforated sheet metal $3 \mathrm{~mm}$ thick-perforations as shown in Fig. 2:

a) The first concave sieve: (hole concave) $11 \mathrm{~mm}$ dia. round holes (193.87 to $367.5 \mathrm{~cm}^{2}$ (1:0.896) perforation to soled area) . The number of concave holes, 55 per $100 \mathrm{~cm}^{2}$

b) The second concave sieve: (hole concave) $9 \mathrm{~mm}$ dia. round holes (178.128 to $367.5 \mathrm{~cm}^{2}$ (1:1.063) perforation to soled area). The number of concave holes, 76 per $100 \mathrm{~cm}^{2}$

c) The thread concave sieve: (hole concave) $7 \mathrm{~mm}$ dia. round holes (157.017 to $367.5 \mathrm{~cm}^{2}$ (1: 1.341) perforation to soled area). The number of concave holes, 111 per $100 \mathrm{~cm}^{2}$

d) Sieves dimensions are $15 \mathrm{~cm}$ wide, $24.5 \mathrm{~cm}$ long and $3 \mathrm{~mm}$ thick.

- The clearance between cylinder and concave sieve is constant, 10 and $4 \mathrm{~mm}$ at inlet and outlet respectively (there is no possibility to change).

Experiments were performed on lentil crop at Research Farm of Gemmeza Agricultural Research Station, Gharbia Governorate, Egypt. The performance of the threshing were tested and evaluated according to the following criteria: (Machine capacity, $\mathrm{kg} / \mathrm{min}$ - unthreshed seed losses, \% cleaning efficiency, \%, total seed damage, \% - threshing efficiency, $\%$ the independent variables were four cylinder speeds: 15.14 , $18.18,20.21$ and $22.25 \mathrm{~m} / \mathrm{s}$; four feeding rates: 8, 10, 12 and $15 \mathrm{~kg} / \mathrm{min}$ and three hole diameter for sieves: 11,9 and $7 \mathrm{~mm}$. Some of physical properties of lentil crop Giza 9 are shown in Table 2. 

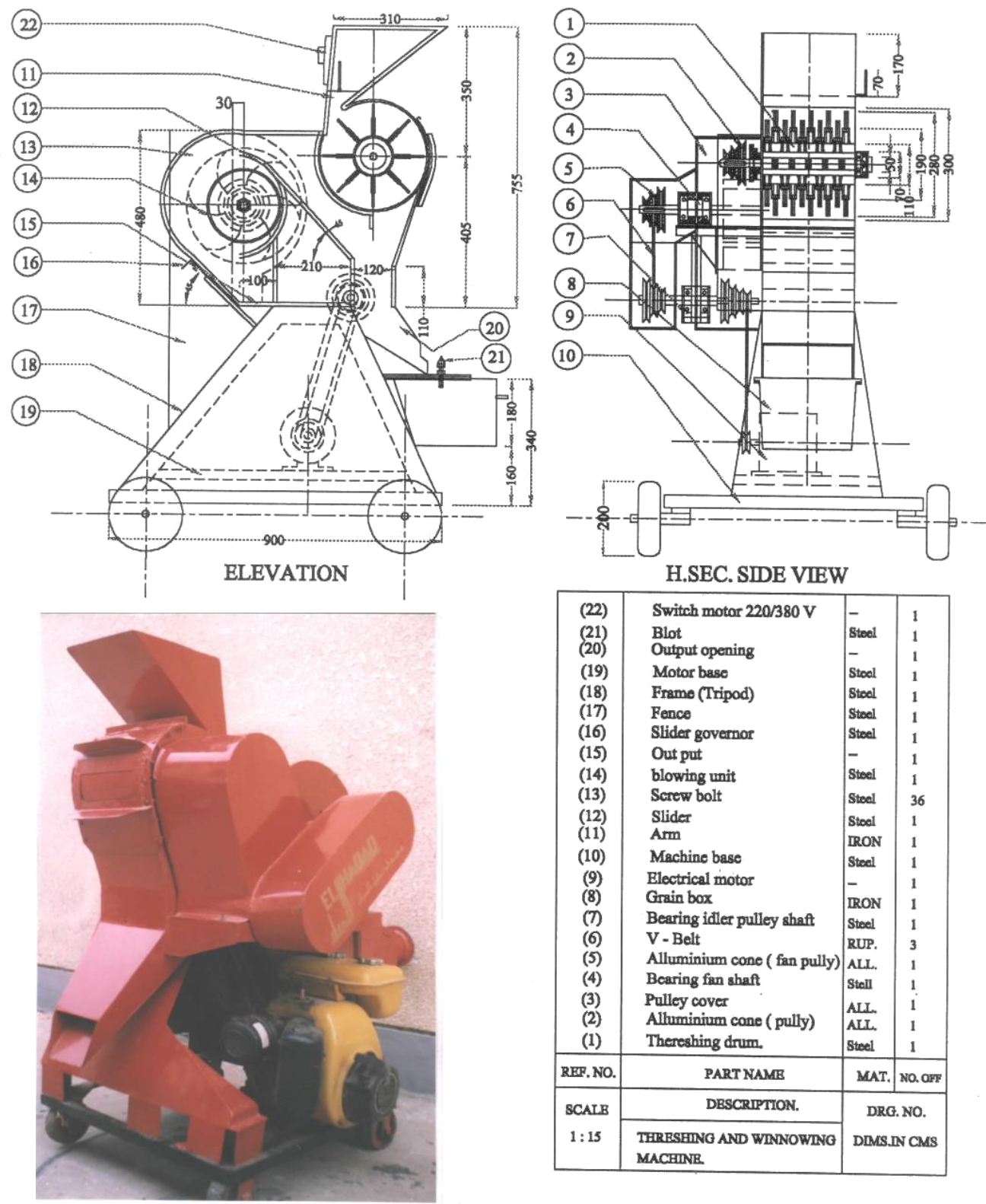

\begin{tabular}{|c|c|c|c|}
\hline (22) & Switch motor $220 / 380 \mathrm{~V}$ & - & 1 \\
\hline$(21)$ & $\begin{array}{l}\text { Blot } \\
\text { Output opening }\end{array}$ & $\begin{array}{l}\text { Steel } \\
-\end{array}$ & $\begin{array}{l}1 \\
1\end{array}$ \\
\hline (19) & Motor base & Stoel & 1 \\
\hline (18) & Frame (Tripod) & Steol & 1 \\
\hline (17) & Fence & Streel & 1 \\
\hline (16) & Slider governor & Steel & 1 \\
\hline (15) & Out put & - & 1 \\
\hline (14) & blowing unit & Steel & 1 \\
\hline (13) & Screw bolt & Steel & 36 \\
\hline $\begin{array}{l}\text { (12) } \\
\text { (11) }\end{array}$ & $\begin{array}{l}\text { Slider } \\
\text { Arm }\end{array}$ & Stoel & 1 \\
\hline $\begin{array}{l}\text { (11) } \\
\text { (10) }\end{array}$ & $\begin{array}{l}\text { Arm } \\
\text { Machine base }\end{array}$ & IRON & 1 \\
\hline (10) & Machine base & Steel & 1 \\
\hline (9) & Electrical motor & - & 1 \\
\hline (8) & Grain box & IRON & 1 \\
\hline (7) & Bearing idler pulley shaft & Steel & 1 \\
\hline (6) & V-Belt & RUP. & 3 \\
\hline (5) & Alluminium cone ( fan pully) & ALI. & 1 \\
\hline (4) & Bearing fan shaft & Stell & 1 \\
\hline (3) & Pulley cover & ALL. & i \\
\hline (2) & Alluminium cone ( pully) & $\overline{A L I}$ & 1 \\
\hline (1) & Thereshing drum. & Steel & 1 \\
\hline REP. NO. & PART NAMB & MAT. & No. ors \\
\hline SCALB & DBSCRIPTION. & \multirow{2}{*}{\multicolumn{2}{|c|}{$\begin{array}{c}\text { DRG. NO. } \\
\text { DIMS.IN CMS }\end{array}$}} \\
\hline $1: 15$ & $\begin{array}{l}\text { THRESEING AND WINNOWDNG } \\
\text { MACEINR. }\end{array}$ & & \\
\hline
\end{tabular}

Fig.1 : Threshing and winnowing machine model El-Haddad WZ -1 for small holding, (Original machine). Designed and constructed by (El-Haddad, 2000) and patent applied for 280 - 84

-The machine has obtained a prize competition for the best innovations and inventions of industrial (Dr -Wagdy El-Haddad) from Arab Organization for Industrialization (factory of kader El Harbi). 


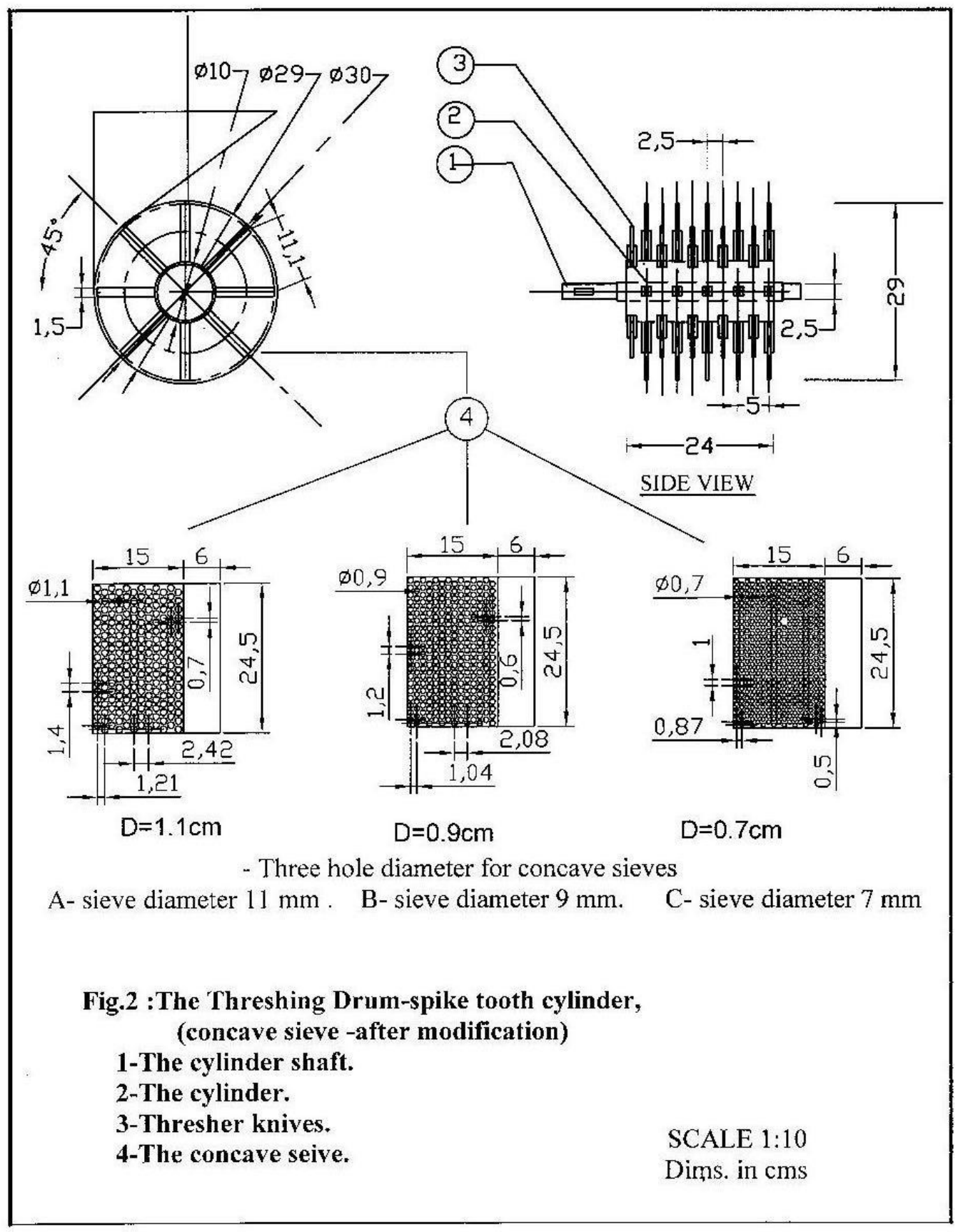

Fig.2: The concave sieves group was manufactured for small thresher to suit threshing lentil crop. 
Table 1: The present machine specifications

\begin{tabular}{|l|l|}
\hline \multicolumn{1}{|c|}{ Items } & \multicolumn{1}{c|}{ Specifications } \\
\hline Length, Width and Height, $\mathrm{cm}$ & 124,71 and 145 \\
\hline Mass, kg & 154 \\
\hline Source of power & Solar engine, $5 \mathrm{hp}(3.75 \mathrm{~kW})$ \\
\hline Type of cylinder & Spike tooth \\
\hline (Cylinder), Length $\times$ Diameter, cm & $24 \times 29$ \\
\hline Cylinder knives, cm & $\begin{array}{l}\text { Total of }(40) \text { peg tooth, (9.5) long, } \\
(1.5) \text { wide and (0.5) thickness }\end{array}$ \\
\hline Input opening for crop, cm & $30 \times 25$ \\
\hline Output opening for straw, cm & $25 \times 12$ \\
\hline Output opening for grain, cm & $19 \times 12$ \\
\hline Blower dimensions, cm & $(30)$ diameter and (10) wide \\
\hline
\end{tabular}

Table 2: Physical properties of lentil crop

\begin{tabular}{|l|c|}
\hline \multicolumn{1}{|c|}{ Items } & Average \\
\hline Stem length, cm & 36 \\
\hline Stem diameter, mm & 3.5 \\
\hline Number of branches/plant & 10 \\
\hline Number of pods/plant & 40 \\
\hline Mass of 1000 seeds, gm & 25 \\
\hline Diameter of seed, $\mathrm{mm}$ & 3.76 \\
\hline Thickness of seed, $\mathrm{mm}$ & 2.24 \\
\hline
\end{tabular}

*Taking samples of ten lentil crop (Giza 9)

\section{-Measuring equipments:}

Speedometer - grain moisture content meter - balance - stop watch - hot wire anemometer for measuring air velocity, $\mathrm{m} / \mathrm{s}$.

\section{Measurements:-}

During test performance of the threshing machine the following parameters were measured and taken into consideration.

The samples were taken periodically from the machine outlet and placed in polyethylene bags. The time of run of the experiment was measured by means of a stop watch. A tachometer was used to measure the cylinder drum speed of the threshing machine. The percentage of threshed seeds and unthreshed pods was evaluated as a ratio of the total weight threshed and unthreshed seeds. Also, the physical properties of lentil crop were 
very important to select the adjustable concave sieves group for small thresher and chose their best for threshing lentil crop.

The laboratory test was carried out on a sample of threshed grain to determine the total seed damage (visible and invisible damage). The visible grain damage percentage was determined by separating the broken grain from a mass of 50 grams sample taken randomly from the threshed grain, whilst the invisible grain damage percentage was calculated by the germination test. Three replicates of 50 seeds were germinated at Petri dishes on a paper filter covered with water and incubated at $308^{\circ} \mathrm{K}\left(25^{\circ} \mathrm{C}\right)$ for 8 days. After threshing operation for each test, the amount of lentil seeds was recorded. An average of three replicates of this procedure was taken. The threshing output (threshing capacity), $\mathrm{kg} / \mathrm{min}$; the total losses $(\%)$ power consumption $(\mathrm{kW})$, useful power $(\mathrm{kW})$, and specific energy requirements $(\mathrm{kW} . \mathrm{h} / \mathrm{M})$ were estimated for each test.

\section{a) Machine Productivity (threshing capacity):}

Time of threshing process was measured by stop watch to determine the capacity of machine, $\mathrm{kg} / \mathrm{min}$. Machine productivity was calculated as the following:-

Machine productivity $=\frac{\mathrm{P}_{\mathrm{w}}}{\mathrm{t}}, \mathrm{kg} / \mathrm{h}$

Where:

$\mathrm{P}_{\mathrm{w}}=$ Mass of total seeds output, $\mathrm{kg}$ and

$\mathrm{t}=$ Time consumed in threshing operation, $\mathrm{h}$.

(Total seeds output, $\mathrm{kg} .=$ threshed seeds + total seed damage + unthreshed seeds)

\section{b) Cleaning efficiency:}

The following relationship was used to determine the cleaning efficiency:

$$
\mathrm{E}_{\mathrm{cl}}=\frac{\mathrm{M}_{\mathrm{ts}}-\mathrm{M}_{\mathrm{a}}}{\mathrm{M}_{\mathrm{ts}}} \times 100, \%
$$

Where:

$$
\begin{aligned}
& E_{\mathrm{cl}}=\text { Cleaning efficiency, } \% \\
& \mathrm{M}_{\mathrm{a}}=\text { Mass of impurities, } \mathrm{kg} . \\
& \mathrm{M}_{\mathrm{ts}}=\text { Mass of total seeds, } \mathrm{kg} .
\end{aligned}
$$

\section{c) Unthreshed seeds:}

Unthreshed seeds were calculated according to the following formula: 
Unthreshing seeds $=\left(\mathrm{W}_{\mathrm{us}} / \mathrm{W}_{\mathrm{ts}}\right) \times 100$

Where:

$$
\begin{aligned}
& \mathrm{W}_{\mathrm{us}}=\text { Mass of unthreshing seeds, } \mathrm{g} \text { and } \\
& \mathrm{W}_{\mathrm{ts}}=\text { Mass of total seeds, } \mathrm{g} .
\end{aligned}
$$

\section{d) Seeds damage percentage were calculated as follows:-}

Seed damage $=\mathrm{M}_{\mathrm{ds}} / \mathrm{M}_{\mathrm{ts}} \times 100$

Where:

$$
\begin{aligned}
& M_{d s}=\text { Mass of seed damage, } g \text { and } \\
& M_{t s}=\text { Mass of total seeds, } g .
\end{aligned}
$$

\section{e) Threshing efficiency:}

The threshing efficiency $\left(\mathrm{E}_{\mathrm{t}}\right)$ was estimated according to the following formula (Mishra and Desta 1990)

Threshing efficiency, $\%=100-\left(\mathrm{W}_{2} / \mathrm{W}_{1}\right) \times 100$

Where:

$$
\begin{aligned}
& \mathrm{W}_{1}=\text { Total mass of seed in the sample, } \mathrm{g} \text { and } \\
& \mathrm{W}_{2}=\text { Mass of unthreshing seed in the sample, } \mathrm{g}
\end{aligned}
$$

\section{f) Consumed power:}

Consumed power was calculated by accurately measuring the decrease in fuel level in fuel cylinder immediately after carrying out each treatment. The following formula was used to determine consumed power (Hunt, 1983):

$$
\mathrm{EP}=\left[\mathrm{Fc} \times \frac{1}{60 \times 60}\right] \rho_{\mathrm{f}} \times \text { L.C.V. } \times 427 \times \eta_{\mathrm{th}} \times \eta_{\mathrm{m}} \times \frac{1}{75} \times \frac{1}{1.36}, \mathrm{~kW}---(6)
$$

Where:

F.C = Fuel consumption, (1/h).

$\mathrm{P}_{\mathrm{f}} \quad=$ Density of fuel, $\mathrm{kg} / \mathrm{l}$ ), (for solar fuel $=0.85$ ).

L.C.V = Calorific value of solar fuel, $(10000 \mathrm{kcal} / \mathrm{kg})$.

$427=$ Thermo-mechanical equivalent, $(\mathrm{kg} \cdot \mathrm{m} / \mathrm{kcal})$.

$\eta_{\text {th }}=$ Thermal efficiency of the engine, (35\% for diesel engine).

$\eta_{\mathrm{m}}=$ Mechanical efficiency of the engine, (80\% for Diesel engine).

So, the Specific energy can be calculated as following: 
Specific energy requirements $=\frac{\text { Consumed power, }(\mathrm{kW})}{\text { Machine capacity, } \mathrm{Mg} / \mathrm{h}}, \mathrm{kW} \cdot \mathrm{h} / \mathrm{Mg}--(7)$

\section{The costs:}

g) Machine depreciation (Dep.):

Declining balance method employed in calculating depreciation (Barger et al, 1978). The relationships are as follows:

$$
\begin{aligned}
\mathrm{D} & =\mathrm{V}_{\mathrm{n}}-\mathrm{V}_{\mathrm{n}+1} \\
\mathrm{~V}_{\mathrm{n}} & =\mathrm{C}(1-\mathrm{R} / \mathrm{L})^{\mathrm{n}}, \mathrm{V}_{\mathrm{n}+1}=\mathrm{C}(1 \mathrm{R} / \mathrm{L})^{\mathrm{n}+1}
\end{aligned}
$$

Where:

$\mathrm{D}=$ amount of depreciation charged for year $\mathrm{n}+1$

$\mathrm{C}=$ original cost.

$\mathrm{R}=$ the ratio of depreciation rate for used machines. It will be between 1 and 2 normally.

$\mathrm{L}=$ service life.

$\mathrm{n}=$ number representing age of machine in years at beginning of year.

$\mathrm{V}=$ remaining value at any time (R.V.)

h) Interest on investment, housing, taxes and insurance, (IHTI):

It was estimated $13.8 \%$ of the remaining value (Barger et al., 1978).

\section{i) Repairs and maintenance ( $R$ \& $M)$ :}

Repair costs are very high in developing countries and contribute significantly to the total cost. It was estimated $50 \%$ of the initial value, spread over the life of the machine, has been taken (Kaul and Egbo, 1985).

\section{j) Criterion function cost:}

This function can be calculated as the sum of the unit cost $\left(\mathrm{U}_{c}\right)$ plus the losses cost $\left(\mathrm{L}_{\mathrm{c}}\right)$ using the following equation (Helmy, 1988).

$$
\begin{aligned}
& \mathrm{C}_{\mathrm{f}}=\mathrm{U}_{\mathrm{c}}+\mathrm{Lc}, \mathrm{L} \cdot \mathrm{E} / \mathrm{Mg} \\
& \mathrm{Lc}=10^{-2} \mathrm{C}_{\mathrm{pw}}\left(\mathrm{U}_{\mathrm{G}}+0.67^{*} \mathrm{~T}_{\mathrm{GD}}\right), \mathrm{L} \cdot \mathrm{E} / \mathrm{Mg}
\end{aligned}
$$

Where:

$$
\mathrm{C}_{\mathrm{pw}}=\text { Current price of one ton of lentil seeds, }(8000 \mathrm{~L} \cdot \mathrm{E} / \mathrm{Mg}) .
$$


$\mathrm{U}_{\mathrm{G}} \quad=$ Unthreshed seeds, $\%$.

$\mathrm{T}_{\mathrm{GD}}=$ Total seed damage, $\%$.

$*$ Current price of one ton of broken lentil seeds $=0.67 \mathrm{C}_{\mathrm{pw}}$.

\section{RESULTS AND DISCUSSION}

\section{1- Effect of cylinder speed, feed rate and hole diameter of concave sieves on threshing capacity, (total seeds output) $\mathrm{kg} / \mathrm{min}$.}

Data and results of seed output as affected by different variables are shown in Fig. 3.

At feed rate $8 \mathrm{~kg} / \mathrm{min}$ by increasing cylinder speed from 15.14 to 22.25 $\mathrm{m} / \mathrm{s}$ it was found that total seed output increased from 4.5 to 4.7 $\mathrm{kg} / \mathrm{min}$ (by increasing ratio of 0.04 ) at hole diameter of concave sieves 11 $\mathrm{mm}$. This result may be due to increasing cylinder speed tends to increasing damage of grain into small pieces and through out with straw of threshed materials. At feed rate of $8 \mathrm{~kg} / \mathrm{min}$, increasing hole diameter of concave sieves from 7 to $11 \mathrm{~mm}$, the total seed output increased from 4.0 to $4.5 \mathrm{~kg} / \mathrm{min}$ (by increasing ratio of 0.11 ) and from 4.4 to 4.7 $\mathrm{kg} / \mathrm{min}$ (by increasing ratio of 0.06 ) at cylinder speed of 15.14 and 22.25 $\mathrm{m} / \mathrm{s}$, respectively.

\section{2- Effect of cylinder speed, feed rate and hole diameter of concave sieves on unthreshed seed, $(\%)$.}

a) Data and results of unthreshed seed are affected by different variables are shown in Fig. 4.

At feed rate $8 \mathrm{~kg} / \mathrm{min}$, increasing cylinder speed from 15.14 to 22.25 $\mathrm{m} / \mathrm{s}$, it was found that unthreshed seed decreased from 3.70 to $3.21 \%$ at hole diameter of concave sieve $11 \mathrm{~mm}$. At cylinder speed of $20.21 \mathrm{~m} / \mathrm{s}$ when the feed rate increased from 8 to $15 \mathrm{~kg} / \mathrm{min}$, the unthreshed seed increased from 3.45 to $3.83 \%$ at hole diameter of concave sieve $11 \mathrm{~mm}$. At feed rate $8 \mathrm{~kg} / \mathrm{min}$ and cylinder speed of $15.14 \mathrm{~m} / \mathrm{s}$, when the hole diameter for concave sieves increased from 7 to $11 \mathrm{~mm}$, the unthreshed seed increased from 0.85 to 3.70 

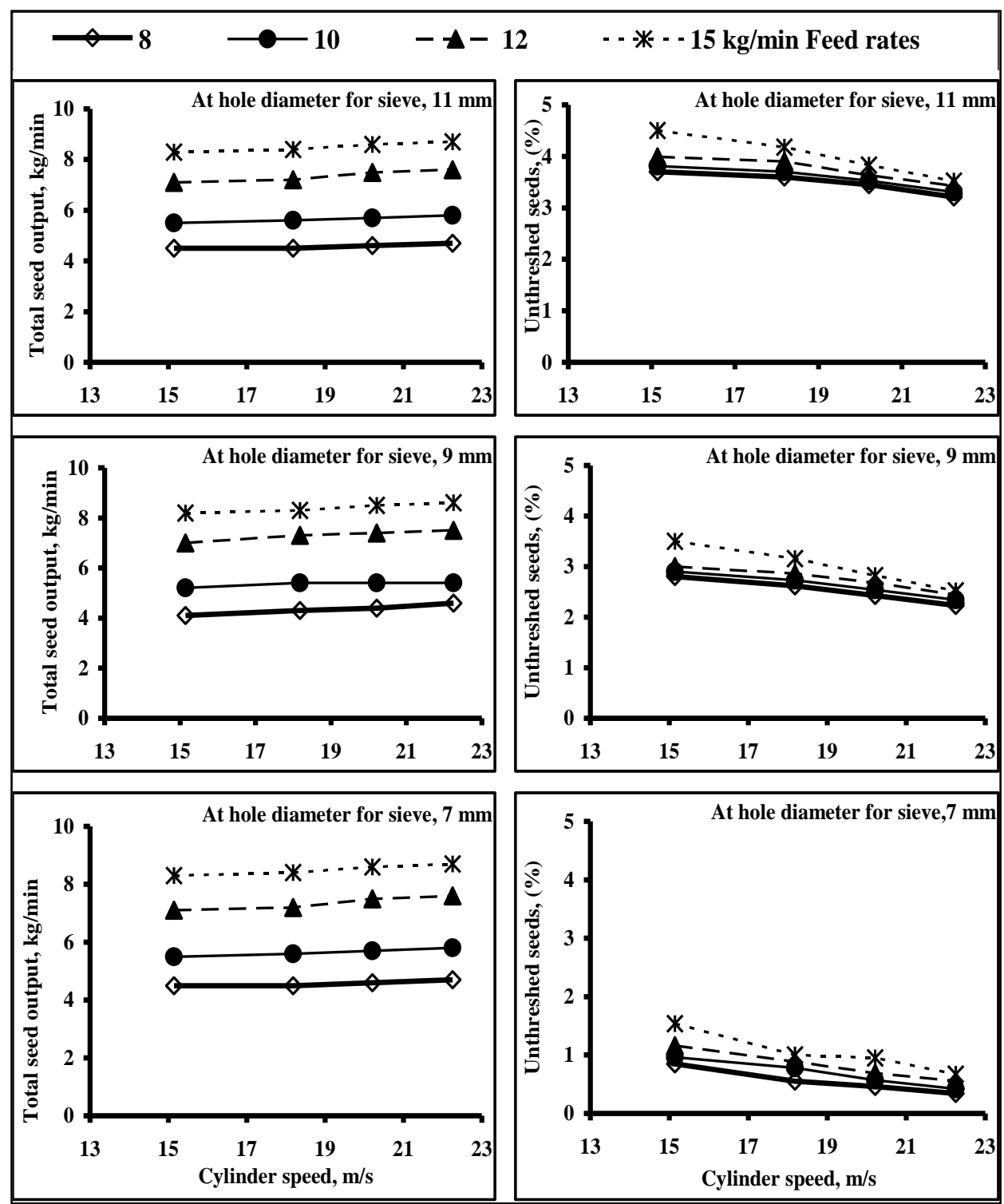

Fig. (3): Effect of cylinder speed, feed rate and hole diameter for concave sieve on total seeds output, ( $\mathrm{kg} / \mathrm{min})$.
Fig. (4): Effect of cylinder speed, feed rate and hole diameter for concave sieve on unthreshed seed, (\%). 


\section{3- Effect of cylinder speed, feed rate and hole diameter of concave sieves on total seed damage, $(\%)$.}

During threshing operation, seed damage occurs mainly due to the impact of knives with seed which is related to the cylinder speed. This damage classified as follows (visible and invisible seed damage). Total seed damage are may reduce the quality and value of the product, so visible seed damage reduce the quality and not reduce the feeding quality of seeds, but invisible seed damage reduce germination ratio (reduce the quality and value of product if seeds are wanted for planting use).

Data and results of total seed damage as affected by different variables are shown in Fig. 5. At feed rate of $8 \mathrm{~kg} / \mathrm{min}$ and hole diameter of sieve $11 \mathrm{~mm}$, when the cylinder speed increased from 15.14 to $22.25 \mathrm{~m} / \mathrm{s}$, the total seed damage increased from 12 to $23 \%$. At cylinder speed of 15.14 $\mathrm{m} / \mathrm{s}$, when the feed rate increased from 8 to $15 \mathrm{~kg} / \mathrm{min}$, the total speed damage decreased from 12 to $4 \%$ at hole diameter of sieve $11 \mathrm{~mm}$. At cylinder speed of $15.14 \mathrm{~m} / \mathrm{s}$ and feed rate of $8 \mathrm{~kg} / \mathrm{min}$,

\section{4- Effect of cylinder speed, feed rate and hole diameter of concave sieves on cleaning efficiency, $(\%)$.}

Increasing feeding rate decreased cleaning efficiency. Also, increasing cylinder speed increased cleaning efficiency. The high cylinder speed increased the velocity of cleaning air results in higher capability of air to carry the foreign material from seeds consequently increased cleaning efficiency. Data and results of cleaning efficiency for modified thresher machine as affected by different variables are shown in Fig. 6 At feed rate $8 \mathrm{~kg} / \mathrm{min}$ and hole diameter for sieve $11 \mathrm{~mm}$, when the cylinder speed increased from 15.14 to $22.25 \mathrm{~m} / \mathrm{s}$, the cleaning efficiency increased from 83.20 to $87.50 \%$ At cylinder speed $15.14 \mathrm{~m} / \mathrm{s}$ and hole diameter for sieve11 mm, when the feed rate increased from 8 to 15 $\mathrm{kg} / \mathrm{min}$ the cleaning efficiency decreased from 83.20 to $75.60 \%$. The maximum cleaning efficiency was $98.99 \%$ at hole diameter for sieve 7 $\mathrm{mm}$ at feed rate $8 \mathrm{~kg} / \mathrm{min}$ and cylinder speed of $22.25 \mathrm{~m} / \mathrm{s}$. 


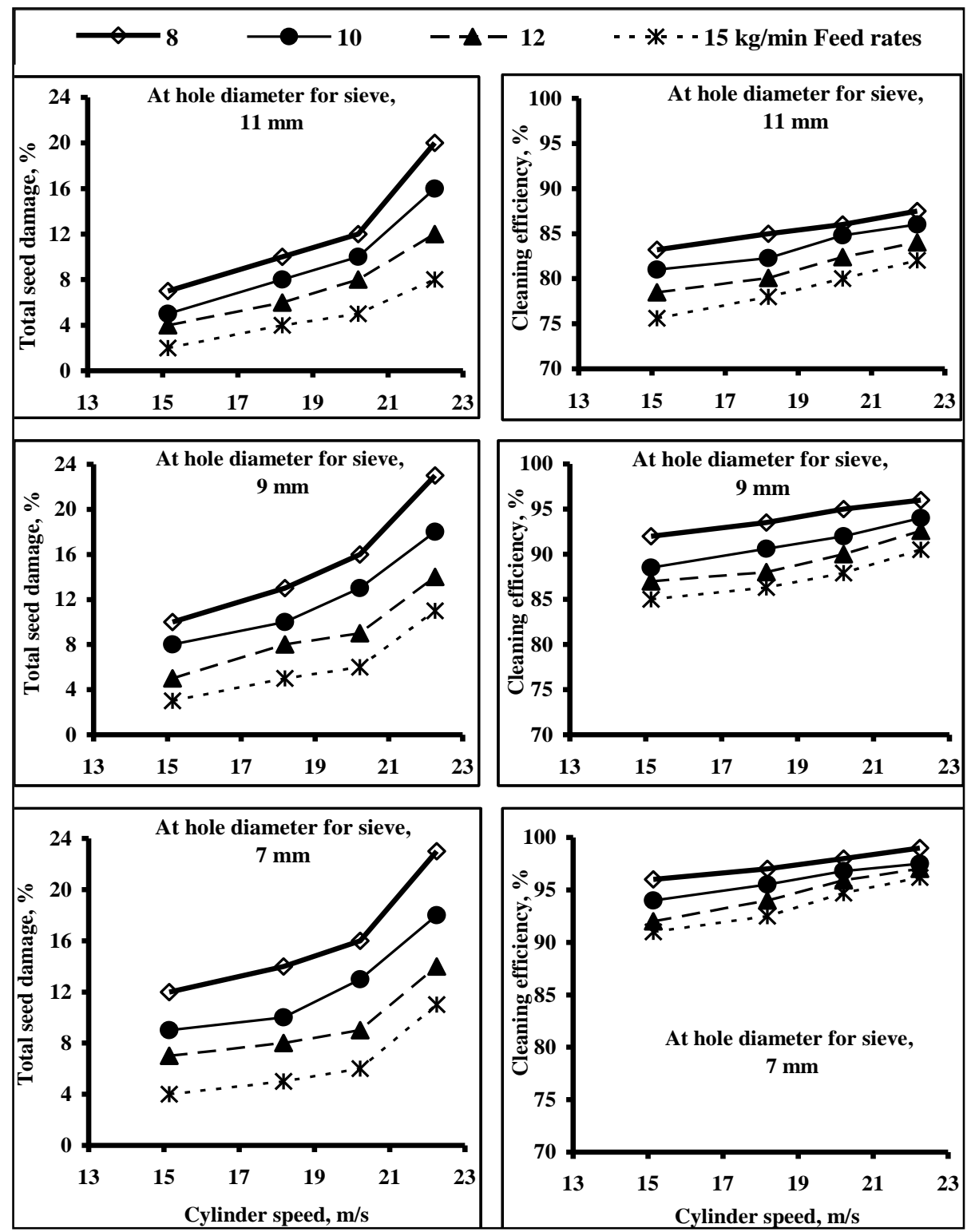

Fig. (5): Effect of cylinder speed, feed rate and hole diameter of concave sieve on total seed damage, $(\%)$.
Fig. (6): Effect of cylinder speed, feed rate and hole diameter of concave sieve on cleaning efficiency, (\%). 


\section{5- Effect of cylinder speed, feed rate and hole diameter for concave sieves on threshing efficiency, $(\%)$.}

Data and results of threshing efficiency for modified thresher machine, as affected by different variables are shown in Fig. 7. At feed rate $8 \mathrm{~kg} / \mathrm{min}$ and hole diameter of concave sieve $11 \mathrm{~mm}$, when the cylinder speed increased from 15.14 to $22.25 \mathrm{~m} / \mathrm{s}$, the threshing efficiency increased from 95.25 to $95.80 \%$. At cylinder speed $15.14 \mathrm{~m} / \mathrm{s}$ and hole diameter of sieve $11 \mathrm{~mm}$, when the feed rate increased from 8 to $15 \mathrm{~kg} / \mathrm{min}$, the threshing efficiency decreased from 95.25 to $94.50 \%$.

At cylinder speed of $15.14 \mathrm{~m} / \mathrm{s}$ and feed rate of $8 \mathrm{~kg} / \mathrm{min}$, when the hole diameter of concave sieves increased from 7 to $11 \mathrm{~mm}$, the threshing efficiency decreased from 97.29 to $95.25 \%$.

\section{6- Effect of cylinder speed, feed rate and straw moisture content on average length of cut straw (Tibbin).}

Length of cut straw is considered an important factor because cut straw (tibbin) is an expensive material. The production of cut straw from one feddan is about $1500 \mathrm{~kg}$ (6 hemel). The price of one hemel is about 90 L.E. So, the machine which gave tibbin whose length rang from 1.5 to 2 $\mathrm{cm}$ this rang is suitable for feeding of animals.

Fig. 8 indicated at feed rate of $8 \mathrm{~kg} / \mathrm{min}$ and straw moisture content of $14 \%$, when cylinder speed increased from 15.14 to $22.25 \mathrm{~m} / \mathrm{s}$, the length of cut straw decreased from 18.33 to $12.33 \mathrm{~mm}$. At cylinder speed of $15.14 \mathrm{~m} / \mathrm{s}$ and straw moisture content $10 \%$, when the feed rate increased from 8 to $15 \mathrm{~kg} / \mathrm{min}$, the length of cut straw increased from 11 to 19.67 $\mathrm{mm}$. At cylinder speed of $15.14 \mathrm{~m} / \mathrm{s}$ and feed rate of $8 \mathrm{~kg} / \mathrm{min}$, when the straw moisture content decreased from 14 to $10 \%$, the length of cut straw decreased from 18.33 to $11 \mathrm{~mm}$. 

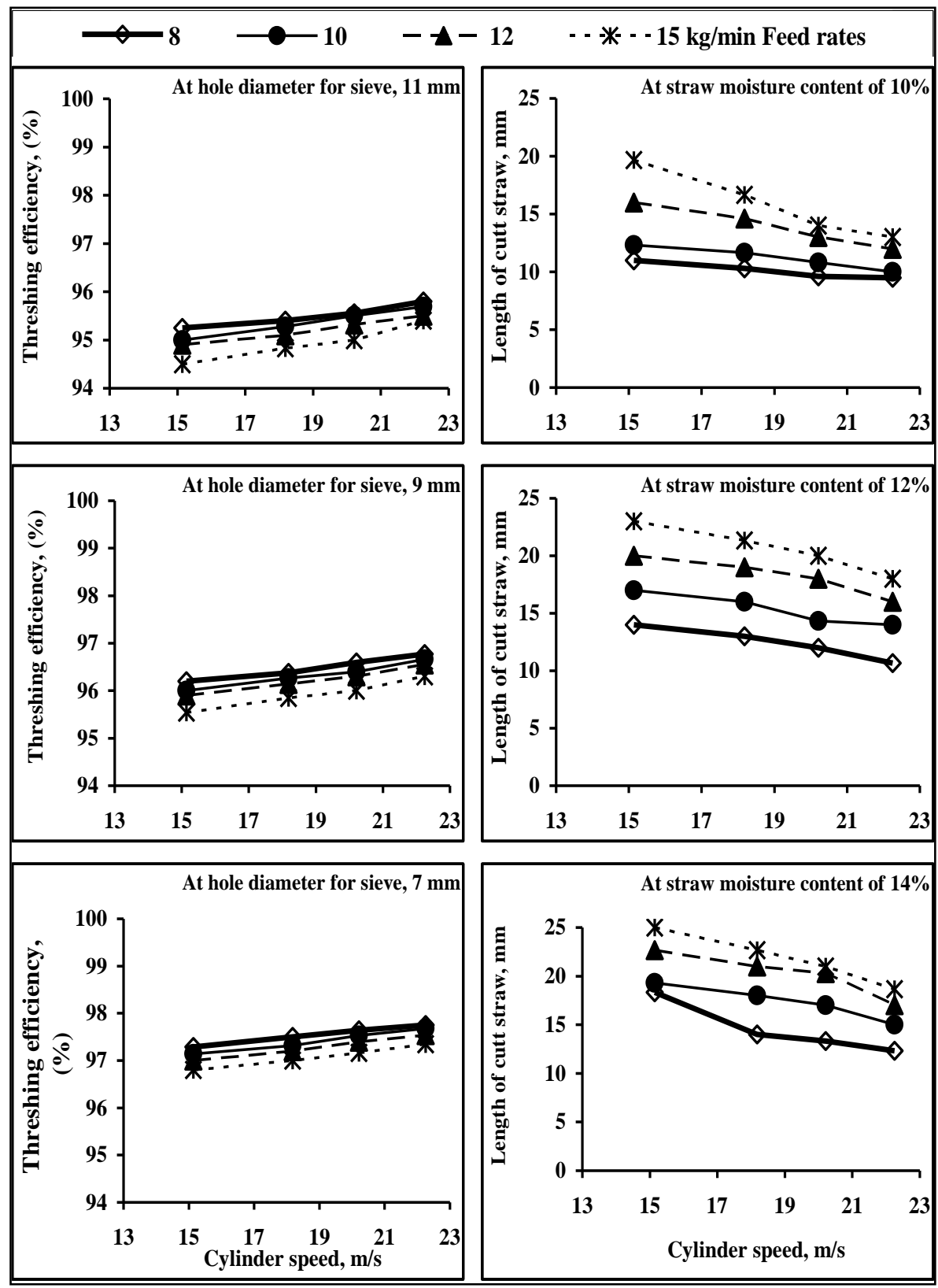

Fig. (7): Effect of cylinder speed, feed rate and hole diameter of concave sieve on

Fig. (8): Effect of cylinder speed, feed rate and straw moisture content on average length of cut threshing efficiency, $(\%)$. straw (Tibbin), mm. 


\section{7- Effect of cylinder speed, feed rate and hole diameter of concave sieves on consumed power, $(\mathrm{kW})$.}

Data and result of consumed power as affected by different variables are shown in Fig. 9. Threshing machine at feed rate $8 \mathrm{~kg} / \mathrm{min}$, increasing cylinder speed from 15.14 to $22.25 \mathrm{~m} / \mathrm{s}$, it was found that power consumed increased from 2.15 to $3.01 \mathrm{~kW}$ at hole diameter of concave sieve $11 \mathrm{~mm}$. Similar results were indicated by El-Haddad, 2004.

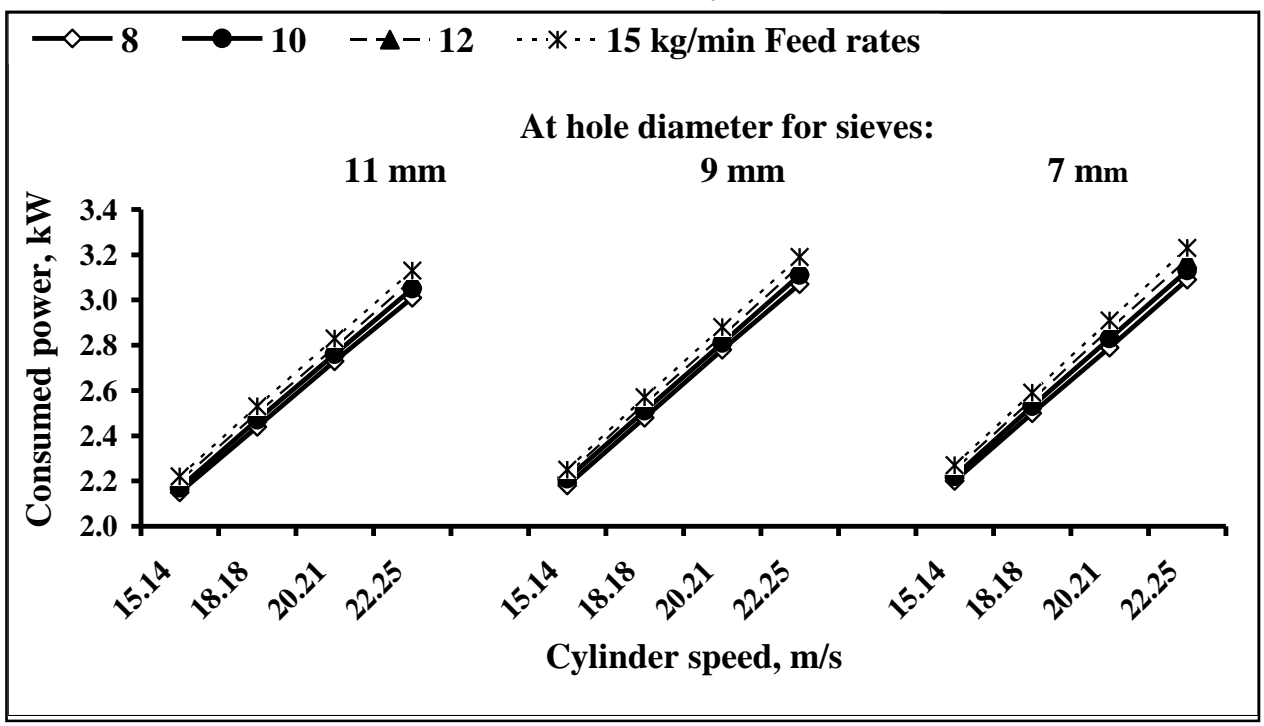

Fig. (9): Effect of cylinder speed, feed rate and hole diameter for sieve on consumed power, $(\mathrm{kW})$.

Threshing machine at $20.21 \mathrm{~m} / \mathrm{s}$, when the feed rate increased from 8 to $15 \mathrm{~kg} / \mathrm{min}$, the power consumed increased from 2.73 to $2.83 \mathrm{~kW}$ at hole diameter for sieve of $11 \mathrm{~mm}$. Threshing machine at feed rate of $8 \mathrm{~kg} / \mathrm{min}$ and cylinder speed of $15.14 \mathrm{~m} / \mathrm{s}$, when the hole diameter for sieves decreased from 11 to $7 \mathrm{~mm}$, the power consumed increased from 2.15 to $2.20 \mathrm{~kW}$. Similar results were indicated by Mahmoud et al. (2007).

\section{8- Cost analysis:}

The items of cost analysis are presented in Table 3. The fabricated cost of a modified thresher machine was about 5000 L.E. the cost of operating hours was determined considering ten years service life of the machine. It could work about 500 hours every year. The cost of operating the thresher for one hour is $14.329 \mathrm{~L} . \mathrm{E} / \mathrm{h}$. and the criterion function cost was 66.978 L.E/Mg. 
Table 3: Criterion function cost for a modified thresher at feed rate $15 \mathrm{~kg} / \mathrm{min}$, cylinder speed $22.25 \mathrm{~m} / \mathrm{s}$, hole diameter for concave sieve of $7.0 \mathrm{~mm}$. and constant moisture content $14 \%$ of lentil seeds

\begin{tabular}{|c|c|c|c|c|c|c|c|}
\hline \multirow[b]{2}{*}{$\begin{array}{l}\text { Modified } \\
\text { thresher }\end{array}$} & \multicolumn{6}{|c|}{ Cost items, LE/h } & \multirow{2}{*}{$\begin{array}{l}\text { Total } \\
\text { cost, } \\
\text { LE/h }\end{array}$} \\
\hline & Dep. & IHTI & $R \& M$ & Labor & Fuel & Oil & \\
\hline $\begin{array}{l}\text { Threshing } \\
\text { machine+ } \\
\text { engine }\end{array}$ & 7.225 & 0.99 & 0.50 & 5 & 0.514 & 0.10 & 14.329 \\
\hline $\begin{array}{l}\text { Modified } \\
\text { thresher }\end{array}$ & $\begin{array}{l}\text { Total } \\
\text { cost, } \\
(\mathrm{L} . \mathrm{E} / \mathrm{h}) \\
\end{array}$ & \multicolumn{2}{|c|}{$\begin{array}{c}\text { Productivity, } \\
\qquad(\mathrm{Mg} / \mathrm{h})\end{array}$} & $\begin{array}{c}\text { Unit } \\
\text { cost, } \\
(\mathrm{L} . \mathrm{E} / \mathrm{Mg})\end{array}$ & \multicolumn{2}{|c|}{$\begin{array}{c}\text { Losses } \\
\text { cost, } \\
(\mathrm{L} . \mathrm{E} / \mathrm{Mg})\end{array}$} & $\begin{array}{l}\text { Criterion } \\
\text { function } \\
\text { cost, } \\
\text { (L.E/Mg) }\end{array}$ \\
\hline $\begin{array}{l}\text { Threshing } \\
\text { machine+ } \\
\text { engine }\end{array}$ & 14.329 & \multicolumn{2}{|c|}{0.522} & 27.45 & \multicolumn{2}{|c|}{39.528} & 66.978 \\
\hline
\end{tabular}

\section{CONCLUSSION}

The results of the present study led to the following conclusion:

1.The seed output increased as the cylinder speed increased, the maximum amount of grain out put was $8.7 \mathrm{~kg} / \mathrm{min}$ at cylinder speed $22.25 \mathrm{~m} / \mathrm{s}$, feed rate of $15 \mathrm{~kg} / \mathrm{min}$ and hole diameter for sieve of $11 \mathrm{~mm}$.

2. The maximum cleaning efficiency was $98.99 \%$ at hole diameter for sieve $7.0 \mathrm{~mm}$ at feed rate $8 \mathrm{~kg} / \mathrm{min}$ and cylinder speed of $22.25 \mathrm{~m} / \mathrm{s}$.

3. The minimum unthreshed grain losses were $0.34 \%$ at cylinder speed of $22.25 \mathrm{~m} / \mathrm{s}$, feed rate of $8 \mathrm{~kg} / \mathrm{min}$ and hole diameter for sieve of $7 \mathrm{~mm}$.

4. The threshing efficiency increased with increase of cylinder speed and decrease of feed rate. The maximum threshing efficiency was $97.75 \%$ at cylinder speed $22.25 \mathrm{~m} / \mathrm{s}$, feed rate $8 \mathrm{~kg} / \mathrm{min}$ and hole diameter for sieve of $7 \mathrm{~mm}$.

5. The minimum length of cut straw was $9.5 \mathrm{~mm}$ at cylinder speed of $22.25 \mathrm{~m} / \mathrm{s}$, feed rate of $8 \mathrm{~kg} / \mathrm{min}$ and straw moisture content of $10 \%$.

6. The maximum consumed power was $3.23 \mathrm{~kW}$ at cylinder speed of $22.25 \mathrm{~m} / \mathrm{s}$, feed rate of $15 \mathrm{~kg} / \mathrm{min}$ and hole diameter for sieve of $7.0 \mathrm{~mm}$.

7. The total threshing cost for a machine operated by solar engine $5 \mathrm{hp}$ $(3.75 \mathrm{~kW})$ costed $14.329 \mathrm{~L} . \mathrm{E} / \mathrm{h}$, while the criterion function cost was 66.978 L.E/Mg. 
Threshing machine was satisfactory where it gave the highest productivity of $8.7 \mathrm{~kg} / \mathrm{min}$, the lowest value of unthreshed seed losses of $0.34 \%$, cleaning efficiency of $98.99 \%$ the threshing efficiency of $97.75 \%$, the highest consumed power of $3.23 \mathrm{~kW}$, the minimum specific energy of $6.188 \mathrm{~kW} . \mathrm{h} / \mathrm{Mg}$ and cutting lengths of $9.5 \mathrm{~mm}$ at drum speed of 22.25 $\mathrm{m} / \mathrm{s}$ and hole diameter for sieve of $7.0 \mathrm{~mm}$. However, the machine threshing cost reached 14.329 L.E/h and the criterion function cost was 66.978 L.E/Mg.

\section{REFERANCES}

Abo El-Naga, H.M.; H. El-Gendy and E. Mosa (2005). Evaluation of local threshing machine performance for threshing lentil crop. Misr J. Ag. Eng., 22(2): 376-388.

Afify, M.K.; M.A. El-Sharabasy and M.A. Ali (2007). Development of a local threshing machine suits for threshing Black seed. Misr J. Ag. Eng. 24(4): 699-724.

Barger, E.L.; J.B. Lujedahl; W.M. Carleton and E.G. Mckibben (1978). Tractor and their power units. $2^{\text {nd }}$, John Wiley \& sons, Inc., New York, USA. pp. 390-399.

Chancellor, W.J. (1981). Substituting information for energy in Agric. Transaction ASAE, (5): 802-807.

El-Haddad, W.Z. (2000). A simplified design and performance study of threshing and winnowing machine suitable for small holdings. M.Sc Thesis, Agric. Mech., Fac. Agric. Kafr El-Sheik, Tanta Univ.

El-Haddad, W.Z. (2004). Manufacture and evaluation chopping threshing and winnowing machine suitable for the requirement of some crops residues recirculation. Ph.D. Thesis, Agric. Mech. Dept., Fac. of Agric., Tanta Univ.

El-Khateeb, H.A.; H. Sorour and M. Saad (2008). Operating factors affecting using two different threshing machines for threshing sunflower heads. Misr J. Ag. Eng. 25(2): 251-270.

Emara, Z. (2006). Modification of threshing drum of a stationary thresher to suit separating flax crop. Misr J. Ag. Eng., 23(2): 324-345.

Helmy, M.A. (1988). Threshing parameters affecting the performance of local and foreign wheat threshing machines. Misr J. Ag. Eng., 5(4): 329-343. 
Hunt, D. (1983). Farm power and machinery management. $8^{\text {th }}$ Ed. Iowa State Uuiv., Press Ames, USA. Ames, Iowa USA: 364-368.

Kadry, M. A. (1987). Prototype a lentil walker puller harvester. Misr J. Ag. Eng., 4(4): 351-364.

Kaul and Egbo (1985). Introduction to Agriculture mechanization "Management and cost analysis" First Published, pp. 172-175.

Mahmoud, A.A.; M. El-Sharabasy and M. Khattab (2007). Development of feeding device in a Turkish threshing machine. Misr J. Ag. Eng., 24(2): 235-258.

Mishra, T.N. and K. Desta (1990). Development and performance evaluation of a sorghum thresher. Agric. Mech. In ASIA. 21(3): 33-37.

Morad, M.M.; M.A. Arnaout and A. Mohamed (2000). Development of the reciprocating mower for harvesting lentil crop. Misr J. Ag. Eng., 17(1): 1-16.

Moussa, A.I. (2006). The effect of selected mechanical threshing parameters on thresh ability of some legume crops. J. Ag. Sci., Mansoura Univ., 31(7): 223-242.

Nashwa El-Tatawy (1999). Self-sufficiency of lentil in Egypt: Current and prospective status. J. Ag. Res., Tanta Univ. 25(3): 139-149.

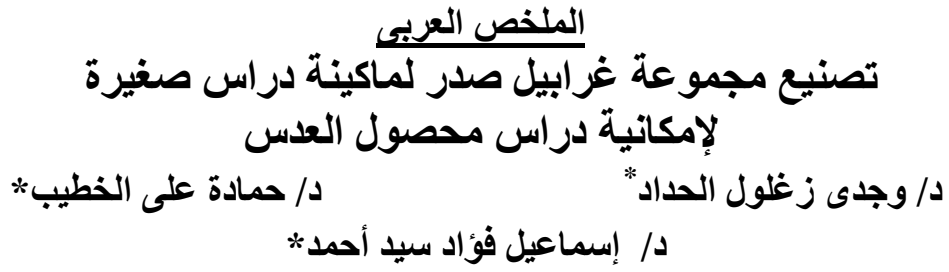

يعتبر محصول العدس من المحاصيل البقولية الغذائية الرئيسية فى مصر ، وذليدية وذلك لكون بذوره

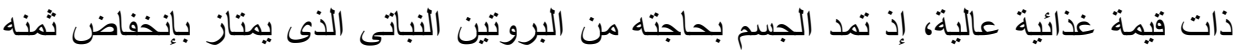

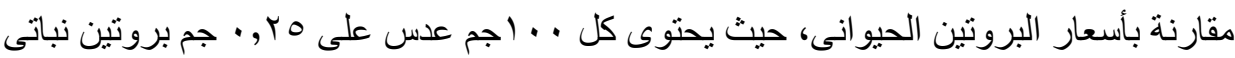

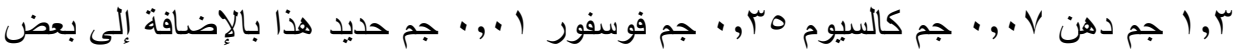

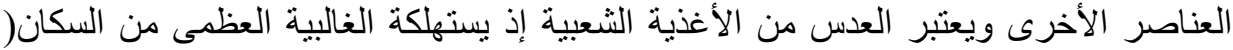

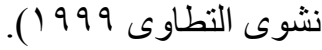
أجريت التجارب بمحطة البحوث الزراعية بالجميزة - محافظة الغربية. وفى هذا البحث نم



معهل بحوث الهنسة الزراعية - مركز البحوث الزراعية ـ دقى - جيزة - مصر. 
الصدر المختلفة التى تم تصنيعها بفتحات دائرية ذو اقطار ل 1 ، 9 ، V مم لتحديد أنسب غربال صدر لتشغيل هذه الآلة مع محصول العدس صنف جيزة 9 يحقق اعلى كفاءة در اس مع أعلى

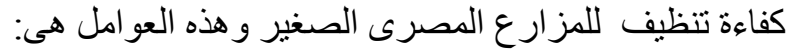

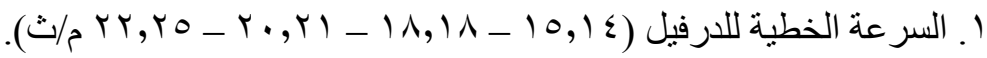

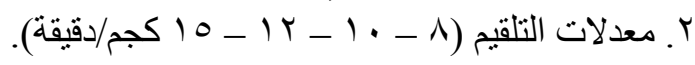

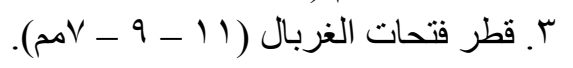

أهم ما خلصت إلية النتائج: أنمات

ا - وجد أن سعة الماكينة تزداد طردياً بزيادة سرعة الدرفيل وهذا يعنى أن أعلى انتاجية

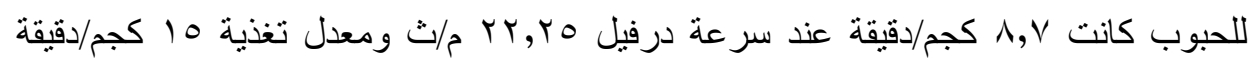

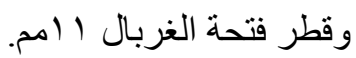

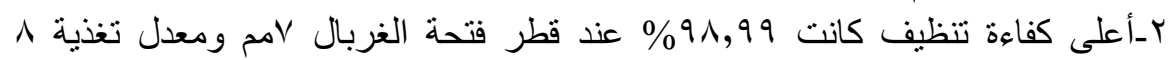

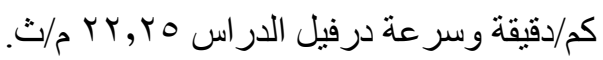

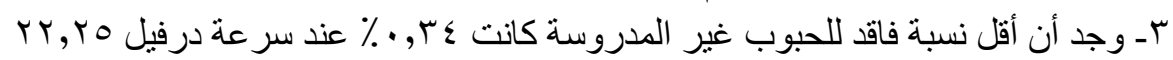

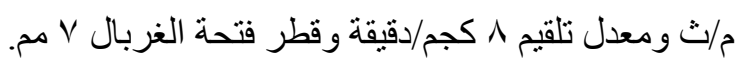

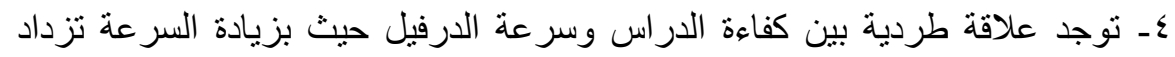

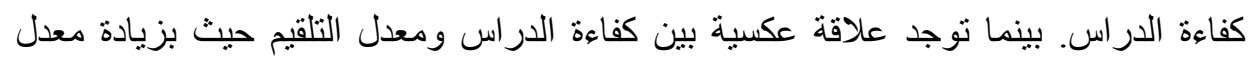



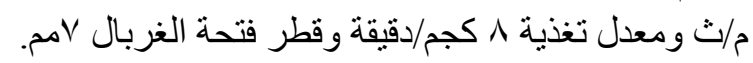

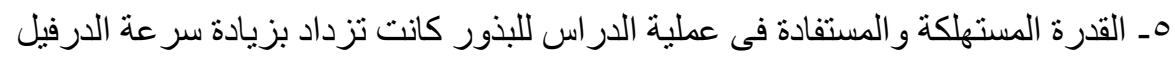

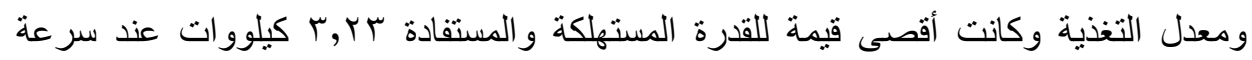



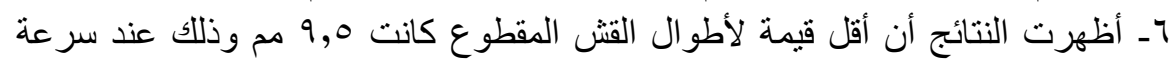

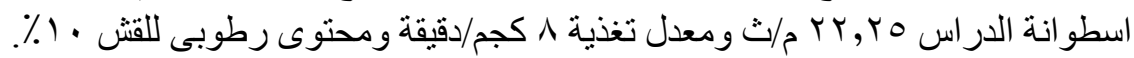

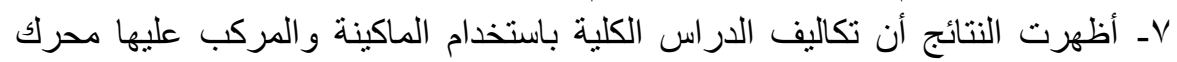

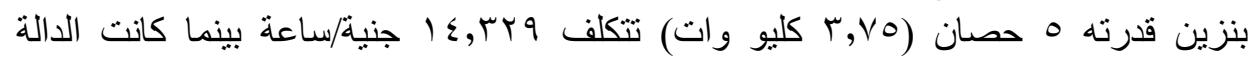
المعيارية لها تكون

آلة الدر اس المعدلة كانت مرضية حيث أعطت أعلى انتاجية \, ر كجم/دقيقة عند أعلى مئى

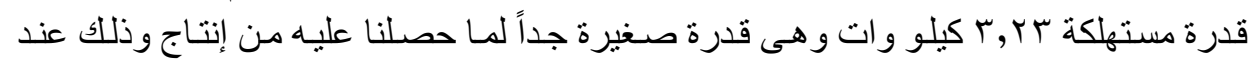

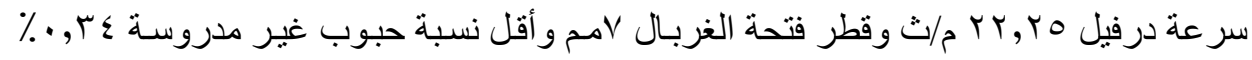

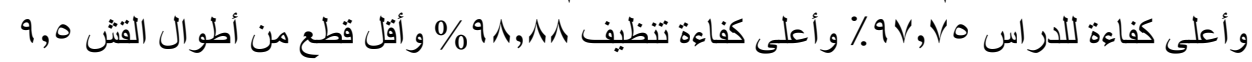

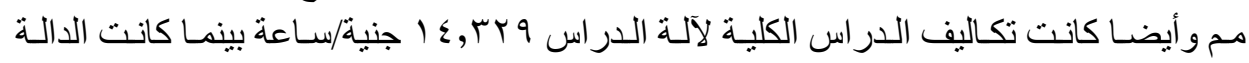

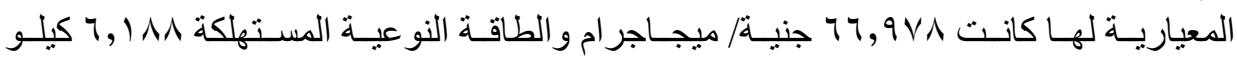
و ات.ساعة/ميجاجر ام. 